\title{
Health-related quality of life of
} patients with squamous cell carcinoma:

a comparison according to tumor location. Braz Oral Res. 2017;31:e105.

Where is read:

(a)Universidade Estadual do Norte do Paraná - Unopar, Londrina, PR, Brazil.

It should read:

(a)Universidade Norte do Paraná - Unopar, Londrina, PR, Brazil.

DOI: 10.1590/1807-3107BOR-2017.vol31.0105erratum 